\title{
Analisis Faktor-Faktor yang Mempengaruhi Tingkat Kemiskinan Kabupaten dan Kota Provinsi Sulawesi Selatan
}

\author{
Suryati $^{1}$ dan Muhammad Syukri ${ }^{2}$ \\ ${ }^{1,2}$ Universitas Andi Djemma Palopo \\ Email: suryatirachmat.syam@gmail.com ${ }^{1}$, syukrimuhammad302@yahoo.co.id ${ }^{2}$
}

\begin{abstract}
The purpose of this study is to analyze the factors that influence the poverty rates in the Regencies and Cities of South Sulawesi Province. This type of research is applied research with secondary quantitative data. The data used in this study are secondary data obtained by the Central Statistics Agency (BPS) including population data; PDRB per capita; $A M H, A H H$, and the poverty rates of Regencies and Cities in South Sulawesi in 2019. Based on the results of the study it can be concluded that the population, per capita GRDP, AMH and AHH simultaneously affect the poverty rates of Regencies and Cities in South Sulawesi. Whereas, partially per capita GRDP variable and AMH variable significantly influence the poverty rates of Regencies and Cities in South Sulawesi. With the coefficient of determination each variable has a contribution to the poverty rate of $57.7 \%$ and the remaining $42.3 \%$ is influenced by other indicators not yet examined. The suggestions for the improvement and development of subsequent research is by adding other variables that can affect poverty rates. With the hope that there will be efforts from all parties, especially the local government, to present superior programs, for example the UMKM development program that can reduce poverty and have an impact on people's welfare.
\end{abstract}

Keywords: Total Population, GRDP, AMH, AHH, Poverty Rates

\begin{abstract}
Abstrak
Tujuan dari penelitian ini yaitu untuk menganalisis faktor-faktor yang mempengaruhi tingkat kemiskinan Kabupaten dan Kota Provinsi Sulawesi Selatan. Jenis penelitian ini adalah penelitian terapan (applied research) dengan data kuantitatif sekunder. Data yang digunakan dalam penelitian ini adalah data sekunder yang diperoleh dari Badan Pusat Statistik (BPS) meliputi data jumlah penduduk; PDRB per Kapita; AMH, AHH, dan tingkat kemiskinan Kabupaten dan Kota di Sulawesi Selatan Tahun 2019. Berdasarkan hasil penelitian dapat disimpulkan bahwa jumlah penduduk, PDRB perkapita, AMH dan AHH secara simultan berpengaruh terhadap tingkat kemiskinan Kabupaten dan Kota di Sulawesi Selatan. Sedangkan, secara parsial variabel PDRB perkapita dan variabel AMH berpengaruh signifikan terhadap terhadap tingkat kemiskinan Kabupaten dan Kota di Sulawesi Selatan. Dengan nilai koefisien determinasi setiap variabel mempunyai kontribusi terhadap tingkat kemiskinan sebesar 57,7\% dan sisanya sebesar $42,3 \%$ dipengaruhi oleh indikator lain yang belum diteliti. Adapun saran dalam perbaikan dan pengembangan penelitian berikutnya yaitu dengan menambahkan variabel lainnya yang dapat mempengaruhi tingkat kemiskinan. Dengan harapan ada upaya dari semua pihak terutama pemerintah daerah untuk menghadirkan program-program unggulan misalkan program pembinaan UMKM yang dapat menurunkan tingkat kemiskinan dan berdampak pada kesejahteraan masyarakat.
\end{abstract}

Kata Kunci: Jumlah Penduduk, PDRB, AMH, AHH, Tingkat Kemiskinan 


\section{PENDAHULUAN}

Masalah kemiskinan adalah persoalan yang sering terjadi di berbagai negara dan bersifat multidimensional [1]. Kemiskinan disebut juga salah satu penyakit dalam ekonomi yang dianggap menjadi sumber berbagai kejahatan dalam berbagai dimensi sehingga harus diselesaikan atau paling tidak dapat dikurangi [2]. Pada dasarnya kemiskinan terjadi disebabkan adanya bencana alam atau dampak dari suatu kebijakan yang menyebabkan menurunnya tingkat kesejahteraan masyarakat [3].

Kemiskinan tidak muncul secara mendadak dan bersifat kompleks. Ia memiliki latar belakang yang cukup panjang dan rumit sehingga sangat sulit untuk mengidentifikasi akar dari masalah kemiskinan yang terjadi [4]. Tidak hanya itu, kemiskinan juga bersifat multidimensional artinya melihat dari banyaknya kebutuhan manusia yang bermacam-macam, maka kemiskinan pun memiliki aspek primer berupa kemiskinan akan aset, organisasi sosial politik, pengetahuan, dan keterampilan, serta aset sekunder berupa kemiskinan akan jaringan sosial, sumber-sumber keuangan dan informasi.[5] Dampak dari kemiskinan tersebut yaitu adanya kehidupan masyarakat yang mengalami mal-nutrisi, perumahan yang tidak sesuai, pelayanan kesehatan yang kurang baik, rendahnya tingkat pendidikan dan tidak terpenuhinya kebutuhan primer [6].

Indikator utama kemiskinan menurut Bappenas yaitu kurangnya pangan, sandang dan perumahan yang tidak layak; terbatasnya kepemilikan tanah dan alat-alat produktif; kuranya kemampuan membaca dan menulis; kurangnya jaminan dan kesejahteraan hidup; kerentanan dan keterpurukan dalam bidang sosial dan ekonomi; ketakberdayaan atau daya tawar yang rendah; akses terhadap ilmu pengetahuan yang terbatas [9]. Sedangkan, indikator kemiskinan menurut BPS meliputi ketidakmampuan memenuhi kebutuhan konsumsi dasar (sandang, pangan dan papan); tidak adanya akses terhadap kebutuhan hidup dasar lainnya (kesehatan, pendidikan, sanitasi, air bersih dan transportasi); tidak adanya jaminan masa depan; kerentanan terhadap goncangan yang bersifat individual maupun massa; rendahnya kualitas sumber daya manusia dan terbatasnya sumber daya alam; kurangnya apresiasi dalam kegiatan sosial masyarakat; tidak adanya akses dalam lapangan kerja dan mata pencaharian yang berkesinambungan; ketidakmampuan untuk berusaha karena cacat fisik maupun mental; ketidakmampuan dan ketidaktergantungan sosial [7][8].

Bila dirumuskan suatu kondisi masyarakat yang miskin, maka secara umum kondisi tersebut meliputi kondisi yang tidak dapat memenuhi kebutuhan sehari-hari, masih banyaknya anak-anak menderita kekurangan gizi, tingkat kesehatan yang buruk, tingkat buta huruf yang tinggi, lingkungan yang buruk dan masih kurangnya akses infrastruktur maupun pelayanan publik.[4] Kondisi yang demikian disebabkan karena lapangan kerja yang sulit diperoleh, biaya kebutuhan yang tinggi, rendahnya tingkat pendidikan keluarga, ketergantungan masyarakat terhadap alam dan kondisi yang ada, dan terbatasnya akses terhadap modal usaha [5]. Oleh karena itu, upaya pengentasan kemiskinan harus dilakukan secara komprehensif mencakup berbagai aspek dalam kehidupan masyarakat dan dilaksanakan secara terpadu serta tuntas.

Untuk mengurangi tingkat kemiskinan di Indonesia umumnya dan Sulawesi Selatan pada khususnya, perlu diketahui faktor-faktor yang berhubungan atau mempengaruhi tinggi rendahnya tingkat kemiskinan sehingga pada masa mendatang dapat diformulasikan sebuah strategi atau kebijakan publik yang efektif untuk mengurangi tingkat kemiskinan [5]. Strategi pengentasan kemiskinan seharusnya tidak terpaku pada aspek ekonomi dan fisik saja, tetapi aspek nonfisik (rohaniah) juga perlu mendapatkan tempat yang cukup dalam kebijakan tersebut. Pendidikan agama dan budi pekerti sangat penting untuk dihadirkan dalam kebijakan tersebut terutama dalam penanaman nilai-nilai agama, etika, dan budi pekerti bagi anak-anak dan pemuda dalam menghadapi problematika kemiskinan [2].

Salah satu cara untuk mengurangi kemiskinan adalah dengan cara meningkatkan tingkat kesejahteraan masyarakat dengan berbagai indikator ekonomi yang ditetapkan. Tentunya, dengan menghadirkan program kewirausahaan masyarakat dalam meningkatkan pendapatan masyarakat. Pada prinsipnya, tingkat kesejahteraan masyarakat diukur dengan kondisi bertumbuhnya perekonomian masyarakat. Pertumbuhan ekonomi merupakan proses kenaikan output perkapita dalam jangka panjang. Tidak hanya itu, indikator kesejahteraan tersebut berasal dari berbagai sektor seperti pajak, retribusi, pengelolaan sumber daya alam, dana investasi, dana perimbangan dan dana pembangunan [10].

Data kemiskinan Sulawesi Selatan pada periode 2012-2017 mengalami fluktuasi baik dari jumlah maupun persentase. Tercatat penduduk 
miskin di Sulawesi Selatan September 2017 berjumlah 825,97 ribu jiwa meningkat 29,16 ribu jiwa jika dibandingkan dengan kondisi September 2016. Persentase penduduk miskin September 2017 sebesar $9,48 \%$ juga meningkat 0,1 poin persen dibandingkan Maret 2017 yang besarnya 9,38\% [11] dan tidak menutup kemungkinan pada tahun berikutnya angka kemiskinan akan mengalami peningkatan. Oleh karena itu, harus ada upaya serius pemerintah dalam mengentaskan atau menurunkan angka kemiskinan dan dapat meningkatkan kesejahteran bagi masyarakat. Penelitian ini didukung oleh penelitian yang pernah dilakukan oleh para peneliti lainnya dengan penambahan indikator yang berbeda dan studi kasus yang berbeda [12] [13] [14] [15]. Adapun tujuan dari penelitian ini yaitu untuk menganalisis faktorfaktor yang mempengaruhi tingkat kemiskinan Kabupaten dan Kota Provinsi Sulawesi Selatan.

\section{METODE PENELITIAN}

\section{Jenis Penelitian}

Jenis penelitian ini adalah penelitian terapan (applied research) dengan data kuantitatif sekunder. Penelitian terapan merupakan penelitian yang dikerjakan dengan maksud untuk menerapkan, mengkaji dan mengevaluasi kemampuan suatu teori yang diterapkan dalam pemecahan masalah secara praktis di bidang ekonomi.

\section{Jenis dan Sumber Data}

Data yang digunakan dalam penelitian ini adalah data sekunder. Data sekunder umumnya berupa bukti, catatan atau laporan historis yang telah tersusun dalam arsip yang dipublikasikan dan tidak dipublikasikan. Dalam penelitian ini yang termasuk data sekunder adalah data jumlah penduduk; PDRB per Kapita; Angka Melek Huruf $(\mathrm{AMH})$ dan Angka Harapan Hidup (AHH) Kabupaten dan Kota di Sulawesi Selatan Tahun 2019. Data yang digunakan dalam penelitian ini bersumber dari Badan Pusat Statistik (BPS) Kota Palopo dan Badan Pusat Statistik (BPS) Provinsi Sulawesi Selatan [7], [11].

\section{Prosedur Penelitian}

Prosedur penelitian yang akan dilakukan dalam penelitian adalah sebagai berikut:

\section{Pengumpulan Data}

Pada tahapan ini, peneliti akan mengumpulkan data yang dibutuhkan di BPS baik data yang sudah dipublikasikan maupun yang belum dipublikasikan.

\section{Analisis Deskriptif}

Analisis deskriptif yaitu untuk memberikan gambaran (deskripsi) mengenai penyajian suatu data. Analisis deskriptif tersebut meliputi rata-rata (mean), jumlah (sum) simpangan baku (standard deviation), varians (variance), rentang (range), nilai minimum dan maximum dan sebagainya.

\section{Uji Asumsi Klasik}

Uji asumsi klasik merupakan persyaratan statistik yang harus dipenuhi pada analisis regresi linear berganda yang berbasis Ordinary Least Square (OLS). Uji Asumsi klasik tersebut meliputi Uji Normalitas, Uji Multikolinearitas, Uji Heteroskedastisitas, Uji Autokorelasi dan Uji Linearitas.

\section{Analisis Regresi Linier Berganda}

a. Penentuan model Regresi Linear Berganda Persamaan umum regresi linier berganda adalah:

$Y=\beta_{0}+\beta_{1} X_{1}+\beta_{2} X_{2}+\beta_{3} X_{3}+\beta_{4} X_{4}+\varepsilon \quad 2.1$

Dimana, $Y=$ tingkat kemiskinan, $\beta_{0}=$ konstanta, $\beta_{1}=$ koefisien regresi berganda, $\beta_{2}=$ koefisien regresi berganda, $X_{1}=$ jumlah penduduk, $X_{2}=$ PDRB perkapita, $\mathrm{X}_{3}=\mathrm{AMH}, \mathrm{X}_{4}=\mathrm{AHH}$ dan $\varepsilon=$ kariabel pengganggu (error)

b. Uji Koefisien Determinasi $\left(\mathrm{R}^{2}\right)$

Untuk mengukur seberapa besar kontribusi/ sumbangan variabel $\mathrm{X}$ terhadap $\mathrm{Y}$ dapat ditentukan dengan rumus koefisien diterminan yaitu sebagai berikut:

$$
\mathrm{KD}=\mathrm{R}^{2} \times 100 \%
$$

Dimana, $\mathrm{KD}=$ koefisien determinan dan $\mathrm{R}^{2}=$ koefisien korelasi.

\section{c. Uji Simultan (F)}

Uji $F$ ini digunakan untuk mengetahui pengaruh secara bersama-sama variabel bebas terhadap varibel terikat. Dengan ketentuan, jika F-hitung > F-tabel, maka $\mathrm{H}_{1}$ diterima. Sebaliknya, jika F-hitung < F-tabel, maka $\mathrm{H}_{1}$ ditolak. Atau bisa juga dengan melihat kolom probability pada tabel SPSS dengan $\alpha=0,05$. Jika sig $>\alpha ́ \alpha(0,05)$, maka $\mathrm{H}_{1}$ ditolak. Sedangkan jika

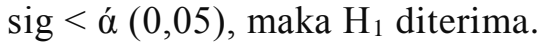

d. Uji Parsial (Uji-T)

Uji ini digunakan untuk mengetahui apakah masing-masing variabel bebasnya secara parsial berpengaruh secara signifikan terhadap variabel terikatnya. Dengan ketentuan T-hitung > $\mathrm{T}$-tabel maka $\mathrm{H}_{1}$ diterima. Dan jika T-hitung < Ttabel, maka $\mathrm{H}_{1}$ ditolak, begitupun jika sig $>\alpha ́$ $(0,05)$ maka $\mathrm{H}_{1}$ ditolak dan jika sig < $\alpha(0,05)$, maka $\mathrm{H}_{1}$ diterima.

\section{Tahapan Kesimpulan dan Saran}

Tahapan untuk menentukan simpulan dan saran atau rekomendasi untuk pemanfaatan penelitian ini oleh pengambil kebijakan. 


\section{HASIL DAN PEMBAHASAN}

\section{Statistik Deskriptif}

Tabel 1. Statistik Deskriptif Variabel

\begin{tabular}{|l|r|r|r|r|r|r|r|}
\hline \multirow{2}{*}{ Variabel } & \multicolumn{1}{|c|}{$\mathrm{N}$} & \multicolumn{1}{c|}{ Minimum } & \multicolumn{1}{c|}{ Maximum } & \multicolumn{2}{|c|}{ Mean } & \multicolumn{1}{c|}{$\begin{array}{c}\text { Std. } \\
\text { Deviation }\end{array}$} & Variance \\
\cline { 2 - 9 } & Statistic & \multicolumn{1}{|c|}{ Statistic } & \multicolumn{1}{c|}{ Statistic } & \multicolumn{1}{c|}{ Stat. } & Std. Error & \multicolumn{1}{c|}{ Statistic } & \multicolumn{1}{c|}{ Statistic } \\
\hline X1 & 24 & 1,53 & 17,13 & 4,1667 &, 67308 & 3,29739 & 10,873 \\
\hline X2 & 24 & 1,25 & 34,03 & 4,1667 & 1,33377 & 6,53410 & 42,695 \\
\hline X3 & 24 & 3,50 & 4,48 & 4,1667 &, 04383 &, 21475 &, 046 \\
\hline X4 & 24 & 3,99 & 4,43 & 4,1667 &, 02584 &, 12659 &, 016 \\
\hline Y & 24 & 1,87 & 6,55 & 4,1667 &, 27308 & 1,33782 & 1,790 \\
\hline $\begin{array}{l}\text { Valid N } \\
\text { (listwise) }\end{array}$ & 24 & & & & & & \\
\hline
\end{tabular}

Statistika deskriptif Tabel 1 menjelakan tentang jumlah data, nilai minimum, nilai maksimum, rata-rata, nilai standar deviasi dan nilai variansi setiap variabel. Variabel independen dalam penelitian ini terdiri atas data jumlah penduduk $\left(\mathrm{X}_{1}\right), \mathrm{PDRB}$ perkapita $\left(\mathrm{X}_{2}\right), \mathrm{AMH}\left(\mathrm{X}_{3}\right), \mathrm{AHH}\left(\mathrm{X}_{4}\right)$ dan tingkat kemiskinan (Y) sebagai variabel dependen.

\section{Uji Asumsi Klasik}

\section{Uji Normalitas Kolmogorov-Smirnov}

Uji normalitas Kolmogorov-Smirnov adalah salah satu jenis dari uji normalitas. Uji ini penting untuk dilakukan untuk mengetahui bentuk normal suatu data. Sebab, suatu model regresi yang baik adalah yang memiliki distribusi data normal atau mendekati normal.

\begin{tabular}{|c|c|c|}
\hline \multicolumn{3}{|c|}{$\begin{array}{l}\text { Tabel 2. One-Sample Kolmogorov-Smirnov } \\
\text { Test }\end{array}$} \\
\hline & & $\begin{array}{l}\text { Unstandardized } \\
\text { Residual }\end{array}$ \\
\hline \multicolumn{2}{|l|}{$\mathrm{N}$} & 24 \\
\hline \multirow{2}{*}{$\begin{array}{l}\text { Normal } \\
\text { Parameters }\end{array}$} & Mean & ,0000000 \\
\hline & $\begin{array}{l}\text { Std. } \\
\text { Deviation }\end{array}$ & 1,23911744 \\
\hline \multirow{3}{*}{$\begin{array}{l}\text { Most Extreme } \\
\text { Differences }\end{array}$} & Absolute &, 183 \\
\hline & Positive & , 183 \\
\hline & Negative &,- 134 \\
\hline \multicolumn{2}{|l|}{ Test Statistic } & , 183 \\
\hline \multicolumn{2}{|c|}{ Asymp. Sig. (2-tailed) } & 138 \\
\hline \multicolumn{3}{|c|}{ a. Test distribution is Normal. } \\
\hline \multicolumn{3}{|c|}{ c. Lilliefors Significance Correction. } \\
\hline
\end{tabular}

Berdasarkan Tabel 2 yang menunjukan bahwa nilai Asymp. Sig. (2-tailed) 0,138 > 0,05. Ini berarti dapat disimpulkan bahwa data tersebut berdistribusi normal.

\section{Uji Multikolinearitas}

Uji multikolinearitas dilakukan dengan tujuan untuk menguji apakah dalam model regresi ditemukan adanya korelasi (hubungan) antar variabel independen. Bila ditemukan terjadi korelasi, itu berarti terjadi problem multikolinieritas.

\begin{tabular}{|l|l|r|r|}
\hline \multicolumn{3}{|c|}{ Tabel 3. Coefficients $^{\mathrm{a}}$} \\
\hline \multirow{2}{*}{ Model } & \multicolumn{2}{c|}{ Collinearity Statistics } \\
\cline { 3 - 4 } \multicolumn{2}{|c|}{} & Tolerance & \multicolumn{1}{c|}{ VIF } \\
\hline \multirow{4}{*}{1} & (Constant) & & \\
\cline { 2 - 4 } & X1 &, 255 & 4,439 \\
\cline { 2 - 4 } & X2 &, 248 & 4,748 \\
\cline { 2 - 4 } & X3 &, 870 & 1,150 \\
\cline { 2 - 4 } & X4 &, 882 & 1,133 \\
\hline \multirow{2}{*}{ X3 } & & & \\
\hline
\end{tabular}

a. Dependent Variable: Y

Tabel 3 menunjukan bahwa nilai Tolerance setiap variabel > 0,1 dan nilai Variance Inflating Factor $(V I F)<10,00$. Sehingga, berdasarkan kriteria pengujian tersebut menunjukan bahwa variabel independen tidak terjadi multikolinearitas.

\section{Uji Homokedastisitas}

Uji homokedastisitas bertujuan untuk menguji apakah dalam model regresi terjadi atau terdapat ketidaksamaan varians dari rersidual dari pengamatan setiap variabel. 


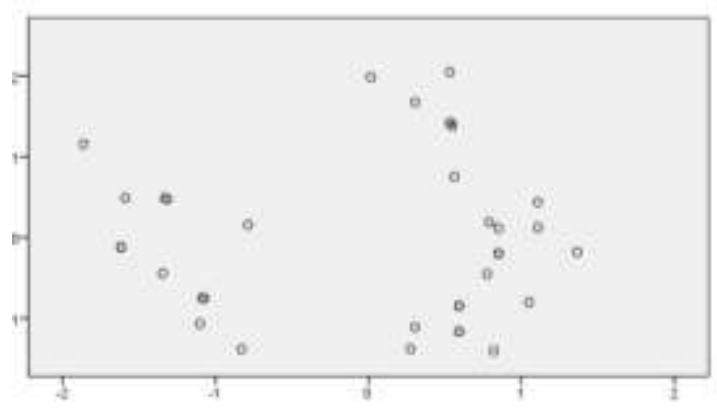

Gambar 1. Grafik Scatterplot

Gambar 1 menunjukan bahwa titik-titik menyebar secara acak pada sumbu $\mathrm{Y}$ dan tidak membentuk model yang baik. Sehingga, model tersebut memenuhi syarat untuk menjadi model yang baik karena merupakan model yang homoskedastisitas yang varians dari nilai residual pengamatan setiap variabel bersifat tetap.

\section{Uji Autokorelasi}

Uji autokorelasi bertujuan untuk menguji model regresi linear apakah terdapat korelasi antara kesalahan pengganggu pada periode- $t$ dengan kesalahan pengganggu pada periode sebelumnya.

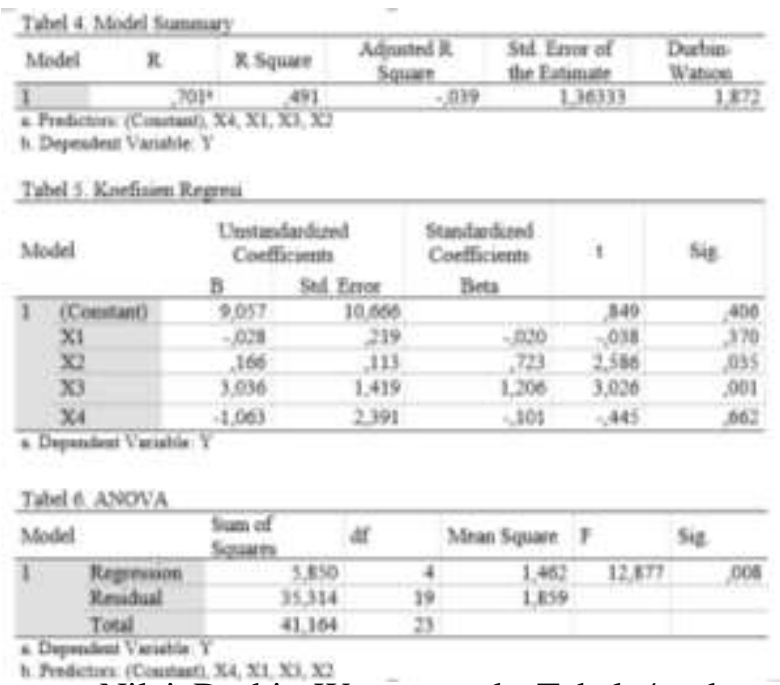

Nilai Durbin-Watson pada Tabel 4 sebesar 1,701 akan dibandingkan dengan nilai tabel yang memiliki signifikansi $\alpha=5 \%$, jumlah sampel 24 dan jumlah variabel independen 4 . Karena, nilai tersebut lebih besar dari batas atas $(d u) 1.77$ dan kurang dari 4- $d u$ itu berarti tidak terdapat autokorelasi.

\section{Uji Linearitas}

Uji linieritas dilakukan dengan melihat scatterplot pada Gambar 1, jika sebaran tidak menunjukkan pola tertentu pada bentuk gambar maka dikatakan asumsi linieritas memenuhi syarat. Sehingga, pada Gambar 1 tersebut menunjukkan scatterplot tidak membentuk pola tertentu dan model tersebut memenuhi syarat untuk menjadi model yang baik karena asumsi linieritas terpenuhi.

\section{Analisis Regresi Linear Berganda}

\section{Model Regresi}

Berdasarkan hasil pengolahan data dengan menggunakan bantuan software komputer maka diperoleh hasil sebagaimana dalam Tabel 5 . Berdasarkan Tabel tersebut dapat dirumuskan persamaan regresi liniear yaitu:

$Y=9,057-0,028 X_{1}+0,166 X_{2}+3,036 X_{3}$

$$
-1,063 X_{4}
$$

Persamaan regresi ini memiliki makna bahwa nilai konstanta sebesar 9,057 berarti jika setiap variabel independen nilainya 0 , maka variabel dependent nilainya konstan yaitu 9,057. Selanjutnya, jika koefisien regresi setiap variabel independen bertambah, maka akan mempengaruhi peningkatan variabel dependen. Begitu pula sebaliknya, jika koefisien regresi setiap variabel independen mengalami penurunan, maka akan mempengaruhi terjadinya pengurangan nilai variabel dependen.

\section{Uji F}

Hipotesis.

- $\mathrm{H}_{0}$ : Tidak ada pengaruh antara jumlah penduduk, PDRB perkapita, AMH dan AHH terhadap tingkat kemiskinan.

- $\mathrm{H}_{1}$ : Ada pengaruh antara antara jumlah penduduk, PDRB perkapita, AMH dan AHH terhadap tingkat kemiskinan.

Tabel 6 menunjukan bahwa nilai $F_{\text {hitung }}$ yaitu 12,877 dan nilai $F_{\text {tabel }}$ yaitu 2,78. Sehingga $F_{\text {hitung }}>$ $F_{\text {tabel }}(12,877>2,78)$ dan nilai signifikansinya 0,008 $<0,05$. Berdasarkan kriteria tersebut maka dapat disimpulkan bahwa jumlah penduduk, PDRB perkapita, AMH dan AHH terhadap tingkat kemiskinan Kabupaten dan Kota di Sulawesi Selatan.

\section{Uji T}

Tabel 5 menunjukan bahwa nilai $\mathrm{T}_{\text {hitung }}$ untuk setiap variabel berbeda-beda dan nilai $\mathrm{T}_{\text {tabel }}$ yaitu 1,71. Untuk variabel jumlah penduduk $\left(\mathrm{X}_{1}\right)$ nilai $\mathrm{T}_{\text {hitung }}<\mathrm{T}_{\text {tabel }}(-0,038<1,71)$ berarti $\mathrm{H}_{1}$ ditolak; variabel $\mathrm{PDRB}$ perkapita $\left(\mathrm{X}_{2}\right)$ nilai $\mathrm{T}_{\text {hitung }}>\mathrm{T}_{\text {tabel }}$ $(2,586>1,71)$ berarti $\mathrm{H}_{1}$ diterima; $\mathrm{AMH}\left(\mathrm{X}_{3}\right)$ nilai $\mathrm{T}_{\text {hitung }}>\mathrm{T}_{\text {tabel }}(3,026>1,71)$ berarti $\mathrm{H}_{1}$ diterima dan AHH $\left(\mathrm{X}_{4}\right) \quad(-0,445<1,71)$ berarti $\mathrm{H}_{1}$ ditolak. Berdasarkan kriteria tersebut variabel $\mathrm{X}_{1}$ dan $\mathrm{X}_{4}$ berarti $\mathrm{H}_{1}$ ditolak, hal ini berarti variabel jumlah penduduk $\left(\mathrm{X}_{1}\right)$ dan $\mathrm{AHH}\left(\mathrm{X}_{4}\right)$ tidak memiliki pengaruh terhadap tingkat tingkat kemiskinan Kabupaten dan Kota di Sulawesi Selatan. Sedangkan, untuk variabel $\mathrm{X}_{2}$ dan $\mathrm{X}_{3}$ berarti $\mathrm{H}_{1}$ diterima, hal ini berarti variabel PDRB perkapita $\left(\mathrm{X}_{2}\right)$ dan variabel $\mathrm{AMH}\left(\mathrm{X}_{3}\right)$ memiliki pengaruh terhadap tingkat tingkat kemiskinan Kabupaten dan Kota di Sulawesi Selatan. 


\section{Uji Koefisien Determinasi $\left(\mathbf{R}^{2}\right)$}

Tabel 4 menunjukan bahwa nilai koefisien determinasi (R-Square) yaitu 0,491. Hal ini memiliki makna bahwa jumlah penduduk, PDRB perkapita, Angka Melek Huruf dan Angka Harapan Hidup mempunyai kontribusi terhadap tingkat kemiskinan sebesar $49,1 \%$ sedangkan sisanya sebesar 50,9\% dipengaruhi oleh variabel-variabel lainnya yang belum diteliti.

\section{Pembahasan}

Penelitian ini selaras dengan penelitian yang dilakukan oleh penelitian lainnya yang menganalisis faktor-faktor yang mempengaruhi tingkat kemiskinan dengan studi kasus yang berbeda-beda. Misalkan ada yang menemukan hasil penelitian bahwa faktor yang paling dominan mempengaruhi tinggi rendahnya jumlah kemiskinan di Indonesia yaitu $\mathrm{AHH}$ yang digambarkan masih belum tercapai disebabkan pemerataan pemberian pelayanan kesehatan yang lebih layak diberikan [16]. Hal tersebut sangat mendukung temuan penulis bahwa variabel $\mathrm{AHH}$ tidak memberikan pengaruh secara parsial terhadap tingkat kemiskinan Kabupaten dan Kota di Sulawesi Selatan.

Selanjutnya, penelitian yang mengungkapkan faktor-faktor yang mempengaruhi tingkat kemiskinan di Provinsi Jawa Tengah dengan variabel yaitu PDRB, pengangguran, dan belanja publik [15], kemudian dengan menambahkan faktor lainnya yang meliputi rata-rata lama sekolah, upah minimum regional, tingkat pengangguran, dan tingkat inflasi [17]. Dalam penelitian tersebut menyungkapkan bahwa variabel PDRB sangat mempengaruhi tingkat kemiskinan di Provinsi Jawa Tengah. Hal ini sangat mendukung penelitian yang dilakukan oleh penulis bahwa variabel PDRB memberikan pengaruh yang signifikan terhadap tingkat kemiskinan Kabupaten dan Kota di Sulawesi Selatan.

Penelitian pendukung lainnya yang menambahkan faktor-faktor yang mempengaruhi tingkat kemiskinan, faktor tersebut yaitu pendidikan, pertumbuhan penduduk, inflasi, pengangguran dan pertumbuhan ekonomi [14] [19]. Dalam penelitian tersebut variabel pertumbuhan penduduk memberikan pengaruh terhadap pertumbuhan ekonomi, tetapi tidak tidak signifikan pengaruhnya terhadap tingkat kemiskinan. Hal ini sangat mendukung penelitian penulis yang tidak menemukan pengaruh signifikan antara variabel jumlah penduduk terhadap tingkat kemiskinan Kabupaten dan Kota di Sulawesi Selatan. Dan AMH berpengaruh terhadap naik dan turunnya tingkat kemiskinan Kabupaten dan Kota di Sulawesi Selatan

\section{KESIMPULAN DAN SARAN}

Berdasarkan hasil penelitian dapat disimpulkan bahwa jumlah penduduk, PDRB perkapita, AMH dan AHH secara simultan berpengaruh terhadap tingkat kemiskinan Kabupaten dan Kota di Sulawesi Selatan. Sedangkan, secara parsial variabel PDRB perkapita dan variabel AMH berpengaruh signifikan terhadap terhadap tingkat kemiskinan Kabupaten dan Kota di Sulawesi Selatan. Dengan nilai koefisien determinasi setiap variabel mempunyai kontribusi terhadap tingkat kemiskinan sebesar $57,7 \%$ dan sisanya sebesar $42,3 \%$ dipengaruhi oleh indikator lain yang belum diteliti. Adapun saran dalam perbaikan dan pengembangan penelitian berikutnya yaitu dengan menambahkan variabel lainnya yang dapat mempengaruhi tingkat kemiskinan. Dengan harapan ada upaya dari semua pihak terutama pemerintah daerah untuk menghadirkan programprogram unggulan misalkan program pembinaan UMKM yang dapat menurunkan tingkat kemiskinan dan berdampak pada kesejahteraan masyarakat.

\section{DAFTAR PUSTAKA}

[1] S. Sumarto, M. Vothknecht., and L. Wijaya, "Explaining the Regional Heterogeneity of Poverty: Evidence from Decentralized Indonesia," Work. Pap., no. IV, p. 25, 2014.

[2] B. Benazir and A. Azharsyah, "Analisis Faktor-Faktor yang Mempengaruhi Kemiskinan di Kabupaten Pidie Jaya," in Prosiding Seminar Nasional Pascasarjana (SNP) Unsyiah, 2017, pp. 79-85.

[3] S. Djojohadikusumo, Ekonomi Pembangunan. Jakarta: PT. Pembangunan, 1995.

[4] Y. Yolanda, "Analysis of Factors Affecting Inflation and its Impact on Human Development Index and Poverty in Indonesia," Eur. Res. Stud. J., vol. XX, no. 4, pp. 38-56, 2017.

[5] B. Van Leeuwen, "The Development of Inequality And Poverty In Indonesia, 19322008," Int. Inst. Soc. Hist. Utr. Univ., pp. 132, 2016.

[6] V. Alatas and B. A. Olken, "Targeting The Poor: Evidence From A Field Experiment In Indonesia," Natl. Bur. Econ. Res. Cambridge, 2010.

[7] B. P. Statistik, Data Dan Informasi Kemiskinan Kabupaten / Kota Tahun 2018. Jakarta: Badan Pusat Statistik, 2018. 
[8] B. Bakhtiar, Manajemen Keuangan Daerah (Pengelolaan Keuangan daerah Berbasis Ekonomis, Efesiensi \& Efektifitas). Makassar: PT. Umi Toha, 2017.

[9] Bappenas, "Evaluasi Pelayanan Keluarga Berencana Bagi Masyarakat Miskin (Keluarga Prasejahtera/KPS Dan Keluarga Sejahtera-I/KS-I," Jakarta, 2010.

[10] D. Didiharyono, M. Marsal, and N. Nasruddin, "Multivariate Regression Analysis With KICC Method In Measuring Of Society Welfare In South Sulawesi," J. MATH Sci., vol. 2, no. 2, pp. 5-13, 2017.

[11] B. Sulsel, Sulawesi selatan dalam angka 2018. Makassar: BPS Provinsi Sulawesi Selatan/, 2018.

[12] A. Khabhibi, "Analisis Faktor-Faktor Yang Mempengaruhi Tingkat Kemiskinan," Tesis FE. Univ. Sebel. Maret, 2013.

[13] R. Permana, "Faktor-Faktor Yang Mempengaruhi Tingkat Kemiskinan Di Provinsi Kalimantan Timur," FORUM Ekon. J. Ekon. Manaj. dan Akunt., vol. 18, no. 2, pp. 111-129, 2016.

[14] N. P. A. P. Margareni, I. K. Djayastra, and I. G. . M. Yasa, "Faktor-Faktor Yang Mempengaruhi Kemiskinan Di Provinsi Bali," PIRAMIDA, vol. XII, no. 1, pp. 101110, 2016.

[15] R. Rusdarti and L. K. Sebayang, "FaktorFaktor Yang Mempengaruhi Tingkat Kemiskinan Di Provinsi Jawa Tengah," J. Econ., vol. 9, no. 1, pp. 1-9, 2013.

[16] B. Tisniwati, "Analisis faktor-faktor yang mempengaruhi tingkat kemiskinan di indonesia," J. Ekon. Pembang., vol. 10, no. 2, pp. 32-46, 2012.

[17] MUSA AL-JUNDI, “Analisis Faktor Yang Mempengaruhitingkat Kemiskinan Provinsi-Provinsi Di Indonesia," Tesis Fak. Ekon. UNDIP, 2014.

[18] H. S. DK, "Analisis Faktor Faktor Yang Mempengaruhi Tingkat Kemiskinan Di Sulawesi Selatan," Tesis Fak. Ekon. UNM, 2016.

[19] P. Warr and A. A. Yusuf, "World food prices and poverty in Indonesia *," Aust. J. Agric. Resour. Econ., vol. 58, pp. 1-21, 2013. 